\title{
An Examination of Voluntary Disclosure, Independent Board, Independent Audit Committee and Institutional Ownership
}

\author{
Hisar Pangaribuan ${ }^{* 1}$, Jenny Sihombing ${ }^{1}$, Oluwatoyin Muse Johnson Popoola ${ }^{2}$ and \\ Adminar M. N. Sinaga ${ }^{3}$ \\ ${ }^{1}$ Adventist University of Indonesia, Bandung - Indonesia \\ 2 Tunku Puteri Intan Safinaz School of Accountancy, Universiti Utara Malaysia \\ ${ }^{3}$ PT. Bizinone Indonesia Jaya, Indonesia
}

\begin{abstract}
This study examined the interaction effect of firm size on the impact of the independent board, independent audit committee, institutional ownership and voluntary disclosure. The study also explored the direct impact on the association between firm size, independent board, independent audit committee, institutional ownership and voluntary disclosure. Data collected from the annual report of banking companies listed on the Indonesia Stock Exchange throughout the year of an observational study. Hypotheses developed are tested with the partial least square - structural equation modelling (PLS-SEM) methodology, and the results subsequently interpreted. The results of the study revealed a positive and significant relationship between the independent board, independent audit committee, institutional ownership and firm size on voluntary disclosure in the Indonesia Stock Exchange listed banking companies. It also found that firm size, as a moderating variable, affects institutional ownership on voluntary disclosure. The existence of an independent audit committee aims at increasing the rate of voluntary disclosure in companies. Similarly, the impact of institutional ownership on voluntary disclosure has a consequence on management performance and commitment to enhance complete disclosure of information to the general public and users of financial statements for informed decision making in large companies.
\end{abstract}

Keywords: Voluntary disclosure, board, audit committee, institutional ownership, firm size.

JEL Classification: C12, D83, G21, G38, G40, H11

Paper Type: Research 


\section{INTRODUCTION}

In the Asian continent, one of the causes of the crisis is the low-level implementation of corporate governance, and Indonesia as a country is not an exception. To remedy the potentials of such unwanted circumstances, Indonesia establishes a committee to manage the implementation of corporate governance and policy, the National Committee on Corporate Governance Policy (KNKCG), to formulate policy recommendations, initiate and monitor corporate governance improvements (Asian Development Bank, 2000).

Transparency is one of the corporate governance pillars. The company increases its transparency by disclosing valid and reliable information to the public and users of financial statements. Banking companies are expected to provide adequate voluntary disclosure to external parties. The voluntary disclosure expects to provide useful information to investors and creditors in creating a more stable investment environment (Belkaoui, 2004; Sihombing \& Pangaribuan 2017). Voluntary disclosure as a mechanism can reduce information asymmetry between firm and investors (Akhtaruddin \& Haron, 2010; Jiang et al., 2011). Voluntary disclosure reflects the transparency and accountability of management in performing a business operation (Akhtaruddin \& Haron, 2010; Li et al., 2012).

Conflicts arise when managers choose to disclose or not to disclose certain information. Such conflicts usually arise because of information that reaches the public. Thus, adequate disclosure of information reduces conflict between owners as the principal and managers as the agent (Al-Harun \& Rouf, 2011). Not many companies in Indonesia announce their profits along with detailed voluntary information, most disclosure of the information is made on the classification of information that is common and concerns only about the background of the company (Wijantini, 2006). The manufacturing companies listed on Indonesia Stock Exchange achievement of voluntary disclosure is only at an average of 56 per cent. Based on the assessment of the Organization of Economic Cooperation and Development (OECD) score, the average value of disclosure criteria less than 60 per cent indicates that the level of voluntary disclosure is at a low position and not encouraging (Utama, 2012).

Some countries in Asia (including Indonesia) have a dual board system, which delves on two levels of supervision. They include the board of commissioners as supervisory and board of directors as the executive. In some countries outside of Asia, where the one-tier board system is in operation, there is only one executive supervision, which is the board of directors (Huang, 2010). In this study, a reference to the board represents "a board of commissioner". Therefore, the independent board is an independent board of commissioners.

Voluntary disclosure of annual reports can be well managed if there is an oversight body established for the purpose as an integral part of corporate governance mechanisms. In the implementation of corporate governance, an instrument that is believed to have an essential role in oversight function is the existence of the board (Fama \& Jensen, 1983). The International Financial Corporation Advisory Service in Indonesia (IFCASI, 2014) states that an independent board is a corporate supervisory organ that has no connection to the company except for supervisory functions. Independent board serves to monitor the financial reporting process and monitoring the transparency implementation through better disclosure of information to ensure the availability of clear and useful information (Forum for Corporate Governance in Indonesia, 2000).

An independent party is required for proper supervision. Based on the regulation set by the financial supervisory body in Indonesia, the independent audit committee is established to conduct oversight functions of an entity. The committee as an organ of transparency and accountability has no personal interest in the entity but work through the 
responsibilities of management, shareholders, business relations or family relationships (Indonesia Financial Services Authority, POJK No. 55/POJK.04/2015). The Board is authorized to appoint and establish audit committees in assisting supervisory duties (Indonesia Financial Services Authority, POJK No. 33/POJK.04/2014). The audit committee also monitors the implementation of information disclosure mechanisms to improve the quality of information flows between owners and managers (Rouf, 2011).

Another factor expected to increase voluntary disclosure in an annual report is institutional ownership. Institutional ownership can reduce conflicts of interest between managers and shareholders through reducing opportunistic attitude of managers (Arouri et al., 2014). Institutional ownership has the power by providing incentives to motivate management to disclose reliable and relevant information to the users of financial reports (Mokhtari \& Makerani, 2013).

Another point of concerns with disclosure is that there is a broader difference between small companies and the large companies about the best disclosure practices. The large companies tend to make a better voluntary disclosure because they have good news to deliver to the public (Kaya, 2014). Transparency through information disclosure can increase a company's readiness to compete regionally as well a globally. Voluntary disclosure is considered necessary for research because it can provide adequate information and is expected to support the achievement of sustainable economic growth. Based on the preceding paragraphs, the implementation of the financial services authority regulations concerning directors and the independent board of public companies (Indonesia Financial Services Authority, POJK No. 33/POJK.04/2014), and information and guidelines for the implementation of audit committee work (Indonesia Financial Services Authority, POJK No.55/POJK.04/2015), constitute an essential significant factor and motivation to conduct a more in-depth study about voluntary disclosure. This study is necessary and important as it discusses the interactive effect of firm size influencing the size of an independent board, independent audit committee, and institutional ownership on voluntary disclosure in the banking companies listed on the Indonesia Stock Exchange.

\section{LITERATURE REVIEW, THEORETICAL FRAMEWORKS AND HYPOTHESES DEVELOPMENT}

Corporate governance is a system that regulates and controls parties within the company that creates added value for all stakeholders. Corporate governance provides a balance between parties who possess the power and authority (Monks \& Minow, 2011). As a guide, one of the characteristics to confirm that corporate governance has been appropriately applied is the existence of adequate disclosure of information, where information owned by management is relatively balanced when compared with information in the market.

The annual report is a medium for managers to disclose information to parties outside the company. Disclosure of company information consists of two types, namely: mandatory disclosure and voluntary disclosure. Mandatory disclosure is the minimum information that must be disclosed by management; such disclosures are by regulation to protect debtors, creditors and investors over money entrusted to the company. Voluntary disclosure is a disclosure beyond those required by law, accounting standards or regulatory requirements. Voluntary disclosure is aimed at further protecting outsiders of any money(s) entrusted to the company; such disclosure is believed to increase trust upon the company (Watson et al., 2002).

Companies are expected to provide adequate voluntary disclosure to the external parties. The willingness of management to make adequate voluntary disclosures may contribute to information obtained by prospective shareholders in assessing the quality of the company in the future before making a decision (Lundholm \& Winkle, 2006). 
Not many companies in Indonesia announce profits accompanied by voluntary information such as management's explanation of special events or prospectus information. Mostly, they just announced their earnings with mandatory information such as last year's earnings disclosures (Gregory at al., 2004). This is supported by a statement saying that voluntary disclosures performed by companies in Indonesia are still at a low level (Darmadi, 2013).

The information disclosed is beneficial for potential investors and creditors in making their investment decisions. Voluntary disclosure is a disclosure that is more than just required (Sanjaya \& Young, 2012). Voluntary disclosure is regarded to fill up the information needed by stakeholders to reduce information asymmetries between companies and stakeholders (Jiang et al., 2011). Some companies refuse to perform voluntary disclosure because it is seen that competitors can benefit from information disclosed to the public. Extensive voluntary disclosure of information also seems likely to lead to high cost (Hendriksen \& Breda, 2001; Beattie \& Thomson, 2007). The Conceptual framework of the study is demonstrated in Figure 1.

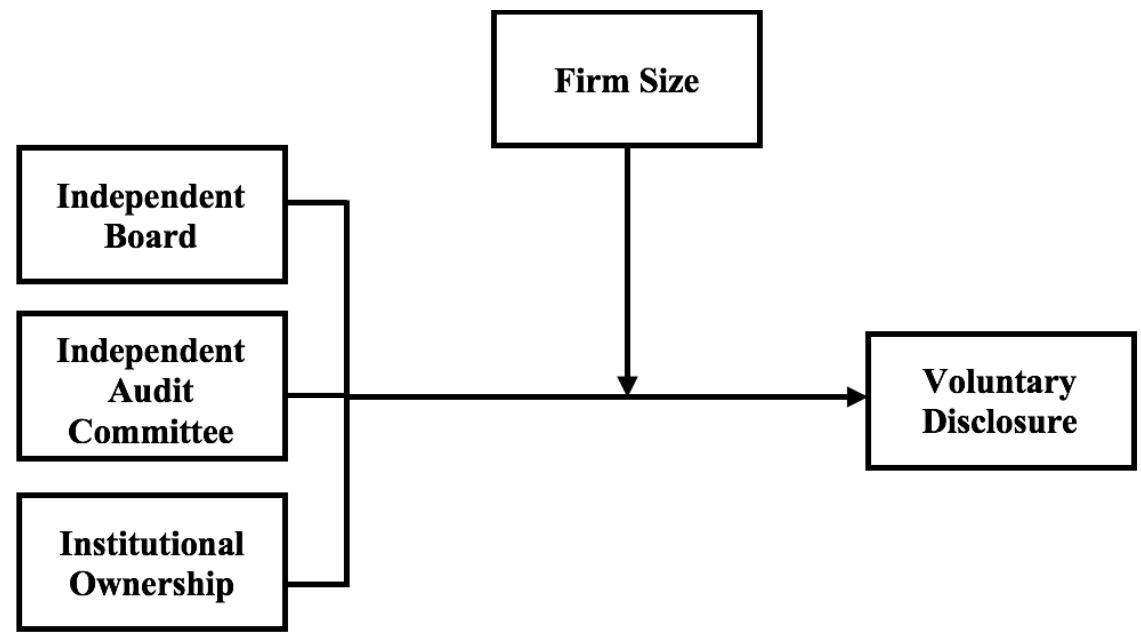

Figure 1. Conceptual framework

\subsection{Independent Board and Voluntary Disclosure}

The implementation of corporate governance regulates the existence of the board to reduce conflict of interest risk between investors and management by conducting supervision through firm regulations (IFCASI, 2014). The Board is responsible for ensuring the balance of management and shareholder interests, as well as monitoring the implementation of corporate governance through the performing of transparency principles about company information (Forum for Corporate Governance in Indonesia, 2000).

Adequate voluntary disclosure in the annual report will be well established if there is an active oversight function that is one aspect of corporate governance mechanisms (Bhasin et al., 2012). An appropriate implementation of corporate governance can be carried out well when the company's operational oversight function runs well. There is often an agency conflict problem, namely between the owners and management. An instrument that is believed to have an essential role in oversight is the presence of the board. The existence of the board alone has not guaranteed the implementation of the principles of corporate governance, especially regarding the protection of investors. 
Therefore, more specific new organs are independent board members. The existence of independent board members within the company could be likened to a presentative of the shareholders in overseeing the activities of the company (Allegrini \& Grreco, 2013).

An independent board is a company organ that has no share, has no affiliation or business relationship with the company and is not a member of the company's management. Indonesia regulation stipulates that the number of board members must consist of at least two members and the composition of independent board members of an enterprise at least $30 \%$ of the total number of existing members (Indonesia Financial Services Authority, POJK No. 33/POJK.04/2014). The independent member does not come from a consulting agency or public accounting firm that serves the company (IFCASI, 2014).

Independent board functions to monitor and control the actions of directors because of their opportunistic behaviour (Jensen \& Meckling, 1976). There is a significant positive correlation between the proportions of independent board members with voluntary disclosure (Chakroun, 2013). Another study suggests that independent boards affect voluntary disclosure (Nandi \& Gosh, 2012). Prior literature to investigate the impact of board proportion on voluntary disclosure found that the proportion of independent board members had no significant impact on voluntary disclosure (Aboagye et al., 2012; Habbash et al., 2016).

\subsection{Independent Audit Committee and Voluntary Disclosure}

The regulation requires public companies to establish an audit committee. The audit committee established to enhance the oversight and accountability roles of the company's board. This Committee is a sub-committee of the executive board with responsibility for overseeing the quality and integrity of the accounting, financial reporting systems, internal control systems, and compliance with applicable regulations. The audit committee is established by the board to assist board duties by overseeing the financial reporting process that has a role to apply objectively to management, external auditors, shareholders, creditors and donors, and also to ensure that each party receives accurate information about the company (Indonesia Financial Services Authority No. 55/POJK.04/2015).

Sarbanes-Oxley obliged public companies to form an independent audit committee. Furthermore, the Indonesian financial inspection body stipulates that the audit committee should be established by the board. The committee is in charge of assisting the board in monitoring and control. It is further stipulated that the number of audit committee members in the firm shall consist of at least three persons and $30 \%$ of its members must be independent members (Indonesia Financial services Authority, POJK No. 55/POJK.04/2015). The audit committee is in charge to oversee the financial reporting process, establishing communication with external auditors, and ensuring that shareholders and creditors can receive financial information (Braiotta et al., 2010).

The regulation of financial services authority in Indonesia (POJK. No.55/POJK.04/2015) provides the terms of audit committee membership, which includes that the audit committee members should have high integrity, ability, knowledge, experience by their field of work, and able to communicate well. The person is required to understand the financial statement and understand the regulations in the field of the capital market and other relevant laws or regulations. The persons are also required to comply with the established code of conduct of the audit committee; he must be willing to improve competence through education and training continually. This Committee must consist of at least 1 (one) person with expertise in accounting or finance. The committee member also is not a person in the public accounting firm, legal consulting firm, public service 
appraiser office or any other party providing insurance services, non-insurance services, appraisal services and / or other consulting services to the public company within the last 6 (six) months, as well as other conditions that are deemed to be able to enhance corporate oversight (Indonesia Financial Services Authority, 2015).

Independent audit committee members can perform better in their oversight tasks, including in reviewing the information released by the management. The members undertake supervision to reduce the occurrence of errors and irregularities in financial statements (Rouf, 2011). The previous study has found that the presence of an independent audit committee has a significant impact on voluntary disclosure (Madi et al., 2014; Gantyowati \& Nugraheni, 2014). Another study has found that independent audit committee has a positive relationship with voluntary disclosure (Rouf, 2011). Based on research conducted by Al-Janadi et al. (2013), there was no significant relationship between the proportions of the independent audit committee with voluntary disclosure. In another study, it was mentioned that an increase in the members of the independent audit committee does not mean that the more experienced audit committee members become increased as well (Adhikary \& Mitra, 2016), and there is no significant impact of independent audit committee on voluntary disclosure (Bedard \& Gendron, 2010).

\subsection{Institutional Ownership and Voluntary Disclosure}

Entities or individuals who have shares of a particular company will have voting rights to take part in corporate decision making. Thus, ownership structures can affect how the company operates. Institutional ownership is the percentage of shares owned by an institution divided by the number of outstanding shares (Mokhtari \& Makerani, 2013). Institutional investors are the best corporate overseers. They are professional investors and experts in evaluating the company's financial performance and financial information (Crane et al., 2016). The presence of an institution in share ownership can monitor and limit the behaviour of managers, influence the process of preparing financial statements and encourage management to present voluntary disclosures (Cornett et al., 2006).

Institutional ownership is regarded as one of the most effective corporate governance mechanisms. Institutions usually have a large percentage of shares in a particular company, so that through the ownership of such shares will provide a stable power to monitor disclosure practices (Al-Harun \& Rouf, 2011). Such high power can provide control over opportunistic behaviour and profit manipulation performed by management (Mokhtari \& Makerani, 2013). Institutional investors have better access to professionals within the company; the circumstance provides distinct advantages to monitor and control corporate policies (Crane et al., 2016). Several studies have revealed that there is a significant positive correlation between the percentage of institutional ownership and voluntary disclosure (Dulacha, 2007, Al-Harun \& Rouf, 2011; Kangarlouei et al., 2013; Audra \& White, 2015), while Azzam (2010) said that concentrated institutional ownership has no significant impact on information disclosure and stock return.

Institutional investors are believed to be able to monitor the management of the company better because the institution has a significant influence and can balance the interests of management and shareholders. Institutional investors commonly have exclusive access to professional parties; the existence of such professionals in the company can encourage management to perform better voluntary disclosure (Solomon, 2010).

Based on research conducted on 138 companies in Turkey has shown that institutional ownership contributes to the development of a better corporate disclosure culture and increase transparency, leading to a lack of information asymmetry and reduced agency costs. The study revealed a significant positive relationship between the 
percentage of institutional ownership and voluntary disclosure (Uyar et al., 2013). A similar case was also found in Kenya, which suggested a significant increase in institutional ownership may increase the extent of voluntary disclosure (Dulacha, 2007).

\subsection{Moderating Effect of Firm Size on Independent Board, Independent Audit Committee, Institutional Ownership and Voluntary Disclosure}

The large companies have the right resources to collect data, to analyze data and to oversee the board in managing the presentation of better financial statements. Large companies also have professional human resources in improving company performance (Botosan, 1997). The larger companies are often becoming the focus of society and government on wealth redistribution, taxes and institutional actions (Scaltrito, 2016). In this study, firm size is measured from the total assets of the company at the end of the accounting period (Alfraih \& Almutawa, 2017).

Company size is also often related to the company's ability to disclose information. The large companies tend to disclose more information because the company's ability can bear a high cost, while the small ones think that voluntary disclosure can threaten themselves in their competition (Scaltrito, 2016). Large companies tend to provide incentives for corporate managers to disclose more information than small companies (Karim et al., 2013). Firm size can moderate so that disclosure can be strengthened or weakened in the research model, the bigger the company, the greater disclosure (Kaya, 2014).

Based on the above theoretical descriptions, this study formulates the following research hypotheses for testing:

$\mathrm{H}_{1}$ : The proportion of independent board member has a significant impact on voluntary disclosure.

$\mathrm{H}_{2}$ : The proportion of independent audit committee member has a significant impact on voluntary disclosure.

$\mathrm{H}_{3}$ : Institutional ownership has a significant impact on voluntary disclosure.

$\mathrm{H}_{4}$ : Company size has a significant impact on voluntary disclosure.

$\mathrm{H}_{5}$ : Company size can moderate the impact of the proportion of independent board member on voluntary disclosure.

$\mathrm{H}_{6}$ : Company size can moderate the impact of the proportion of independent audit committee member on voluntary disclosure.

$\mathrm{H}_{7}$ : Company size can moderate the impact of institutional ownership on voluntary disclosure. 


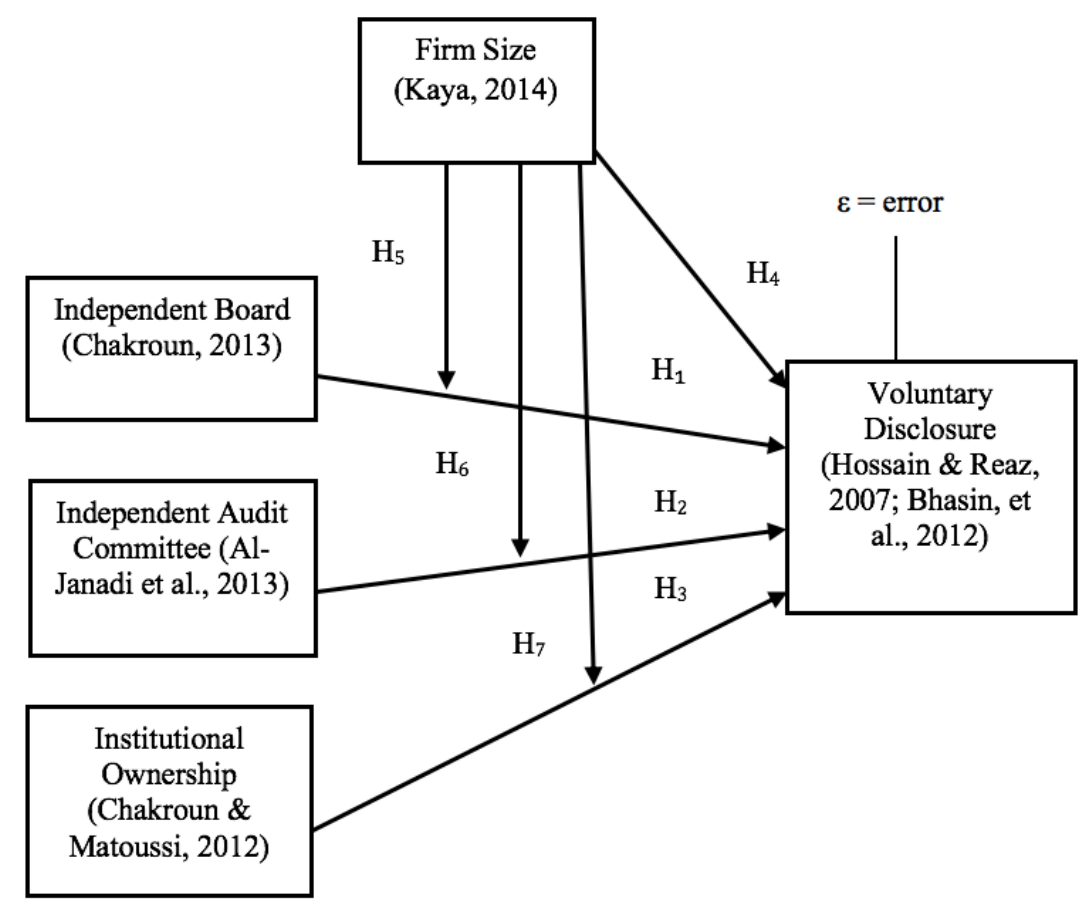

Figure 2. Theoretical framework and Hypotheses of the Study

The research framework in Figure 1 provides an overview of the research model built. This study places independent board, independent audit committee, institutional ownership and firm size as exogenous variables, a further more voluntary disclosure is placed as an endogenous variable. This study also performs firm size as a moderating variable in the model.

\section{METHODOLOGY}

This is a confirmatory explanation study, hypotheses developed and tested aims to determine the direct impact of exogenous variables on the endogenous variable conform to the research model built. The study also aims to examine the moderation effects of firm size on voluntary disclosure. The data used are secondary data, namely from the banks' annual report, the data obtained from the website of Indonesia Stock Exchange for banking companies throughout the year of 2014-2016. There are 43 banks listed on January 2017, it is also found that there are 4 new banks listing between 1 January 2014, and December 2016, thus the sample in this study are 39 banks representing all banking company in Indonesia, for 3 years of observation data, thus there are 117 sample data to be observed and processed. Hypotheses testing for direct and moderation effect is performed with a variance-based approach using smart PLS.

Independent board is measured by the proportion of independent board members in the bank that is from the number of independent board members divided by the total board members (Chakroun, 2013). The Independent audit committee is measured by the proportion of existing independent audit committee members that are from the total number of independent audit committee members divided by the total members of the audit committee (Al-Janadi et al., 2013). Institutional ownership is measured by the percentage of shares held by the institution that is the number of shares held by the institution divided by the total amount of outstanding shares (Chakroun \& Matoussi, 2012). 
Firm size is measured by the total assets of the firm in each observation period (Kaya, 2014). To avoid the big difference range of numbers between the variable of the firm size with other variables in the study, before hypothesis testing is done, total assets in this research must first be converted with natural logarithm.

The calculation of voluntary disclosure scores is performed with the content analysis approach, that is, by allocating a score of 1 if the item is disclosed and a score of 0 if the item is not disclosed by the company. Furthermore, the total items disclosed by the company is divided by the maximum total of all disclosure items. Voluntary disclosure items were adopted from previous research (Hossain \& Reaz, 2007; Bhasin et al., 2012), which has been adapted with the disclosure regulation in Indonesia, and hence, the 48 items of disclosure used in this study. The voluntary disclosure variable consists of 8 classifications. These are general corporate information, corporate strategy information, corporate governance information, financial performance information, risk management information, critical non-financial information, corporate social disclosure and other information.

\section{EMPIRICAL RESULT}

There are 43 banks listed on the Indonesia Stock Exchange, 4 of which are listed the issuance of shares after January 1, 2014, so that 39 banks constituted the research samples during the 3-year, in total, there are 117 research observation data.

\subsection{Descriptive Statistics}

Table 1 provides the research variable description data presented to determine the mean, minimum, maximum and standard deviation of research data. The average value of independent board members is 59\%. The lowest and highest values of independent board proportions are $40 \%$ and $100 \%$, respectively. These findings indicate that all banking companies in Indonesia have met the regulatory requirements of the Financial Services Authority, No. 33/POJK.04 / 2014, which requires a minimum of $30 \%$ of board members must be independent members.

Table 1. Descriptive Statistics of the Study

\begin{tabular}{lllll}
\hline & Mean & Minimum & Maximum & $\begin{array}{l}\text { Standard } \\
\text { Deviation }\end{array}$ \\
\hline Independent Board & 0.59 & 0.40 & 1.00 & 0.10 \\
Independent Audit Committee & 0.85 & 0.50 & 1.00 & 0.21 \\
Institutional Ownership & 0.63 & 0.00 & 1.00 & 0.31 \\
Firm Size (in IDR million) & $124,196,692$ & $1,641,451$ & $1,038,706,009$ & $226,714,741$ \\
Voluntary Disclosure & 0.67 & 0.38 & 0.85 & 0.10 \\
\hline
\end{tabular}

It was also found that the average value of independent audit committee members was $85 \%$. The minimum value of the proportion of independent audit committee members was $50 \%$, while the maximum value was $100 \%$. These findings indicate that all banking companies in Indonesia have met the requirements of the Financial Services Authority regulation, POJK no. 55/POJK.04 / 2015, which requires that members of the independent audit committee have a minimum of $30 \%$ of the total members of the audit committee.

Table 1 also shows that the average value of institutional ownership was $63 \%$, with a minimum value of $0 \%$, which means that there are no banking companies that do not have institutional investors. The data also shows that a bank is $100 \%$ owned by the institution. Improved institutional ownership is believed to improve supervision for the better, and to 
reduce conflicts of interest between owners and agents (Arouri et al., 2014), to improve the quality of information disclosure (Mokhtari \& Makerani, 2013). In the same table, it is also found that the average firm size value proxied by the total asset (in millions) is Rp $124,196,692$, the minimum value of $R p 1,641,451$ and the maximum value is $R p$ $1,038,706,009$. The standard deviation value of firm size is $R p 226,714,740,560,869$ greater than the mean value, which means high data spreading occurs.

It was also found that the average voluntary disclosure score was $67 \%$, with a minimum value of $38 \%$ and a maximum value of $85 \%$. High voluntary disclosure of information demonstrates the fulfilment of management commitment to the delivery of publicly available information so that it is expected to improve management's confidence in making investment decisions. It should also be noted that the overall data on the variables of this research (except for firm size variables) has a reasonably good spreading/distribution of data, proving that the standard deviation value has a value smaller than the mean.

Table 2 describes the tendency that banking companies in Indonesia only reveal general information. Beattie and Thomson (2007) and Gregory et al. (2004) argue that efforts to disclose specific information are perceived to pose a threat to business market competition and contain high costs, while companies may not obtain direct benefits from such disclosures. Based on cost and potential threats to the company, it is likely that fewer banking companies disclose information about financial performance, corporate governance information and risk management information.

Table 2. Descriptive of Voluntary Disclosure

\begin{tabular}{lcccccccc}
\hline & \multicolumn{7}{c}{ Classification of Information Disclosed } \\
\cline { 2 - 8 } & $\begin{array}{c}\text { General } \\
\text { corporate }\end{array}$ & $\begin{array}{c}\text { Corporate } \\
\text { strategy }\end{array}$ & $\begin{array}{c}\text { Corporate } \\
\text { governance }\end{array}$ & $\begin{array}{c}\text { Financial } \\
\text { performance }\end{array}$ & $\begin{array}{c}\text { Risk } \\
\text { management }\end{array}$ & $\begin{array}{c}\text { Key non- } \\
\text { financial }\end{array}$ & $\begin{array}{c}\text { Corporate } \\
\text { social }\end{array}$ & Other \\
\hline $\begin{array}{l}\text { Information } \\
\text { disclosed } \\
\text { (average) }\end{array}$ & 39 & 38 & 24 & 12 & 24 & 31 & 27 & 29 \\
$\begin{array}{l}\text { Percentage } \\
\text { disclosure }\end{array}$ & 100 & 97.44 & 61.54 & 30.77 & 61.54 & 79.49 & 69.23 & 74.36 \\
\hline
\end{tabular}

\subsection{Hypotheses Testing}

The correlations test result, as presented in Table 3, revealed a weak and negative relationship between independent board with voluntary disclosure. Thus, an increase in independent board followed by a lower level of voluntary disclosure can reduce the disclosure cost and the risk of competition caused by disclosure. It has also been found that there was a moderate and positive correlation between the independent audit committee and voluntary disclosure, indicating that the more significant proportion of independent audit committee will be able to perform their functions better in order to motivate management to perform higher disclosure.

It has also been found that there was a low and positive correlation between institutional ownership and voluntary disclosure, the increasing institutional ownership will exercise good oversight (by institution investors), including for higher disclosure of information performed by management. The finding of the correlations also indicated there was a moderate and positive correlation of firm size and voluntary disclosure, the larger firm size, the higher level of voluntary disclosure being performed because larger firms have more resources in doing so. 
Table 3. Correlations Result

\begin{tabular}{lllllll}
\hline & $\begin{array}{l}\text { Ind. } \\
\text { Board }\end{array}$ & $\begin{array}{l}\text { Ind. Aud. } \\
\text { Comm. }\end{array}$ & $\begin{array}{l}\text { Inst. } \\
\text { Owns. }\end{array}$ & Firm Size & $\begin{array}{l}\text { Vol. } \\
\text { Disclosure }\end{array}$ & R-square \\
\hline Ind. Board & 1.000 & -0.085 & -0.257 & -0.298 & -0.236 & \\
Ind. Aud. Comm. & -0.085 & 1.000 & 0.057 & 0.235 & 0.534 & \\
Inst. Owns. & -0.257 & 0.057 & 1.000 & 0.012 & 0.187 & \\
Firm Size & -0.298 & 0.235 & 0.012 & 1.000 & 0.634 & \\
Vol. Disclosure & -0.236 & 0.534 & 0.187 & 0.634 & 1.000 & 0.606 \\
\hline
\end{tabular}

This research is conducted at the level of $\alpha=5 \%$, based on the rule of thumb inner test model, then the results are significant if $t$ statistics $>1.96$. The research model is path analysis. There are seven hypotheses formulated and to be tested with a variance based analysis approach, using PLS-SEM (i.e., Smart PLS) to process the data. The results of testing the direct effects between variables can be found in Figure 3, which is summarized in Table 4.

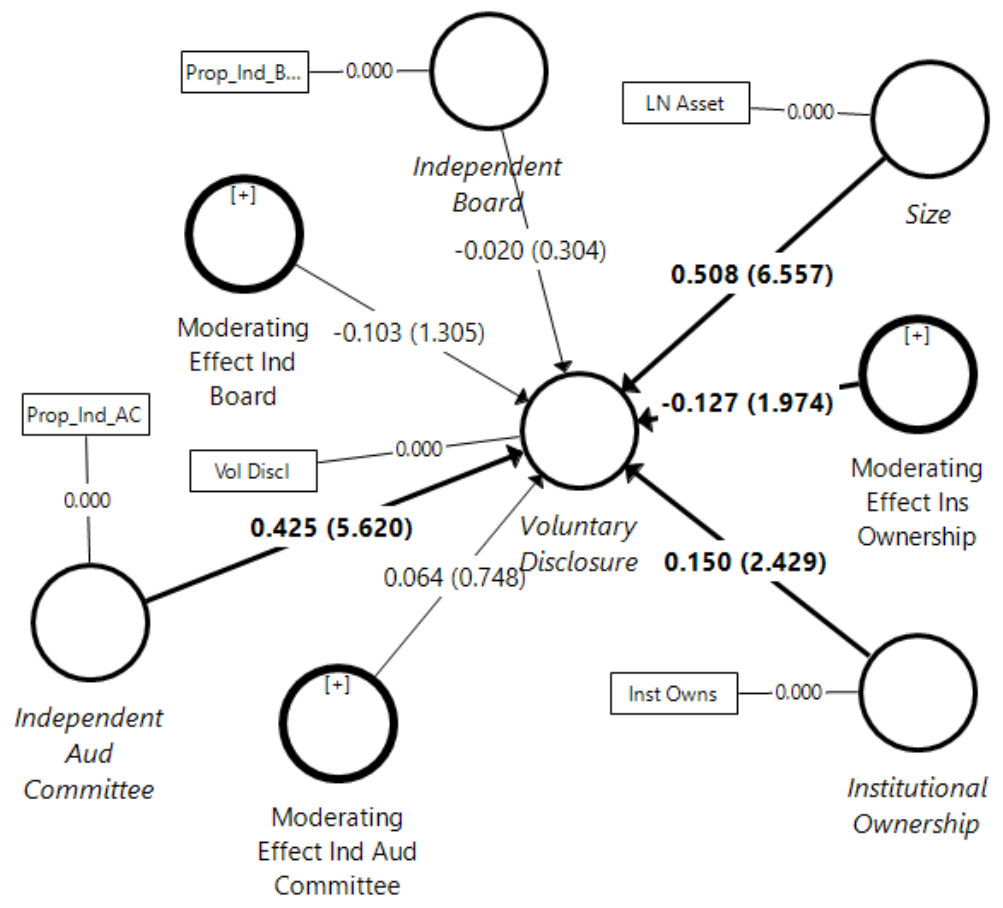

Figure 3. Structural Model Bootstrapping Results

The first finding test, the impact of the independent board on voluntary disclosure indicate that the $t$ statistics is 0.304 , which means that the independent board have no significant impact on voluntary disclosure. The value of the path coefficient of -0.020 indicates that increasing independent board members can decrease the level of voluntary disclosure. Existing boards lack in motivating management to make high voluntary disclosures with high disclosure considerations may pose a threat to business competition and may increase disclosure costs. The test results show that hypothesis $\mathrm{H}_{1}$ is rejected, which demonstrates that the independent board has no significant impact on the increase of voluntary disclosure. These findings are in line with previous studies which state that the board has no significant impact on voluntary disclosure (Aboagye et al., 2012; Habbash et al., 2016). 
The other result of hypothesis testing on the impact of an independent audit committee on voluntary disclosure recorded the path coefficient value of 0.425 with t- statistics of 5.620 . This finding indicates that hypothesis $\mathrm{H}_{2}$ is supported and accepted. An increase in the proportion of independent audit committee member significantly increases voluntary disclosure. The audit committees are responsible for supervising the financial reporting process, which includes striving for a better disclosure level to perform their function adequately. Similarly, the result of this study indicates the importance of establishing a fair proportion of independent audit committee members in Indonesia banking companies so that the level of information disclosure can meet the needs of stakeholders. The result of this study is in line with previous studies which state that the independent audit committee has a significant impact on voluntary disclosure (Rouf, 2011; Madi et al., 2014; Gantyowati \& Nugraheni, 2014).

Table 4. Results of Hypotheses Testing

\begin{tabular}{|c|c|c|c|}
\hline Hypotheses & $\begin{array}{l}\text { Path } \\
\text { Coefficient }\end{array}$ & t statistics & Decision \\
\hline Independent Board $\rightarrow$ Voluntary Disclosure & -0.020 & 0.304 & $\begin{array}{l}\text { Not } \\
\text { Supported }\end{array}$ \\
\hline $\begin{array}{l}\text { Independent Audit Committee } \rightarrow \text { Voluntary } \\
\text { Disclosure }\end{array}$ & 0.425 & 5.620 & Supported \\
\hline $\begin{array}{l}\text { Institutional Ownership } \rightarrow \text { Voluntary } \\
\text { Disclosure }\end{array}$ & 0.150 & 2.429 & Supported \\
\hline Firm Size $\rightarrow$ Voluntary Disclosure & 0.508 & 6.557 & Supported \\
\hline $\begin{array}{l}\text { Independent Board } \rightarrow \text { Voluntary Disclosure } \\
\text { (moderated by firm size) }\end{array}$ & -0.103 & 1.305 & $\begin{array}{l}\text { Not } \\
\text { Supported }\end{array}$ \\
\hline $\begin{array}{l}\text { Independent Audit Committee } \rightarrow \text { Voluntary } \\
\text { Disclosure (moderated by firm size) }\end{array}$ & 0.064 & 0.748 & $\begin{array}{l}\text { Not } \\
\text { Supported }\end{array}$ \\
\hline $\begin{array}{l}\text { Institutional Ownership } \rightarrow \text { Voluntary } \\
\text { Disclosure (moderated by firm size) }\end{array}$ & -0.127 & 1.974 & Supported \\
\hline
\end{tabular}

Institutional ownership has a significant impact on voluntary disclosure with a path coefficient value of 0.150 and t-statistics of 2.429. Thus, the findings support hypothesis $\mathrm{H}_{3}$ of the study. A positive coefficient value indicates that the increasing institutional ownership coincides with the direction and movement of the increase with voluntary disclosure. The results of this study are in line with previous research, which states that the higher the percentage of shares held by institutional shareholders, the higher the level of voluntary disclosure. The institutional shareholders are professional investors and have a strong influence to be more capable in directing management to perform higher voluntary disclosures (Al-Harun \& Rouf, 2011; Audra \& White, 2015).

The other result of this study has reinforced prior findings that the firm size can significantly impact voluntary disclosure in a banking company in Indonesia. The results reflect by a path coefficient value of 0.508 , which means that larger companies will perform better voluntary disclosures compared to smaller ones. The t-statistics value of 6.557 reveals the existence of a significant impact of firm size on the level of voluntary disclosure, and hence, hypothesis $\mathrm{H}_{4}$ of the current study is supported and accepted. This study aligns with previous findings that suggest a significant trend for larger companies to disclose more information to the public, as larger firms have the better capability in disclosing information and have more good news to pass on to public (Scaltrito, 2016; Karim et al., 2013).

The result of the moderation effect test is demonstrated in Table 4, which corresponds to Figure 3. The first moderator test result shown that the path coefficient value is -0.103 and the t-statistics value is 1.305 (i.e., $1.305<1.96$ ), which means that the firm size cannot 
moderate the influence of the proportion of independent board towards voluntary disclosure, which indicates the rejection of hypothesis $\mathrm{H}_{5}$ of the study. Similarly, the results of the path coefficient value of 0.064 and the t-statistics value of 0.748 (i.e., $0.748<1.96$ ) reveal that the firm size cannot moderate the proportion of the independent audit committee on voluntary disclosure. Hence, an indication of the rejection of hypothesis $\mathrm{H}_{\mathrm{s}}$. Furthermore, the result of the third moderation testing of the path coefficient value of 0.127 and t-statistics value of $1.974(1.974$ >1.960) demonstrates firm size significantly moderated the influence of institutional ownership towards voluntary disclosure. Hence, hypothesis $\mathrm{H}_{7}$ of the study is supported and accepted. This study showed that firm size could be a determinant variable in strengthening the impact of institutional ownership towards voluntary disclosure in the Indonesian banking companies.

\section{CONCLUSION}

This study has shown that an independent board has no significant impact on voluntary disclosure. This is because independent board members assume voluntary disclosure can benefit competitors, pose a high level of competition and will incur additional costs for high disclosure to be attained and maintained. Such considerations may discourage the management from making a high voluntary disclosure, given the risk of misuse of disclosed information and costs incurred. Also, the study indicates that a more in-depth study of independent board factor cannot significantly affect the level of voluntary disclosure in the banking companies of Indonesia.

Monitoring efforts to allow a higher level of voluntary disclosure can be made by increasing the independent audit committee. For example, the proportion of independent audit committee members can significantly affect the level of voluntary disclosure. A substantial independent committee member of the committee will be able to determine the direction for a better reporting, and the level of public disclosure will significantly affect the increased voluntary disclosure information available. It is necessary to maintain a good proportion of independent audit committee members in order to make the disclosure level more adequate to allow the stakeholders to obtain sufficient information in their decisionmaking.

This study also found that at a higher percentage of shares held by institutions is significant and more likely to increase voluntary disclosures performed by management. Institutional investors can monitor and influence the behaviour of managers to disclose more information to the public. In essence, institutional ownership can significantly influence voluntary disclosure. The other good news from the results of this study indicated that the larger firm size would significantly do ensure greater voluntary disclosure, which suggests a better commitment for larger companies to disclose full valid and reliable information to the public. The size of a banking firm can be decisive in strengthening or weakening the influence of institutional ownership on voluntary disclosure.

\section{REFERENCES}

Aboagye, O. F., Bedi, I., \& Kwakye, T. O. (2012). Corporate governance and disclosure practice of Ghanaian listed companies, Journal of Accounting in Emerging Economies, 2(2), 140-161.

Adhikary, B. K., \& Mitra, R. K. (2016). Determinants of audit committee independence in the financial sector of Bangladesh. Applied Finance and Accounting, 2(2), 46-56.

Akhtaruddin, M., \& Haron, H. (2010). Board ownership, audit committees' effectiveness, and corporate voluntary disclosures. Asian Review of Accounting, 18(3), 245-259.

Allegrini, M., \& Grecco, G. (2013). Corporate boards, audit committees and voluntary disclosure: evidence from Italian listed companies. Journal Management Governance, 17, 187-216. 
Alfraih, M. M., \& Almutawa, A. M. (2017). Voluntary disclosure and corporate governance: empirical evidence from Kuwait. International Journal of Law and Management, 59(2), 217-236.

Al-Harun, M. A., \& Rouf, M. A. (2011). Ownership structure and voluntary disclosure in annual reports of Bangladesh. Pak. J. Commer. Soc. Sci, 5(1), 129-139.

Al-Janadi, Y., Rahman, R. A., \& Omar, N. H. (2013). Corporate governance mechanism and voluntary disclosure in Saudi Arabia. Research Journal of Finance and Accounting, 4(4), 2536.

Arouri, H., Hossain, M., \& Muttakin, M. B. (2014). Effects of the board and Ownership structure on corporate performance: Evidence from GCC countries. Journal of Accounting in Emerging Economies, 4(1), 117-130.

Asian Development Bank. (2000). Corporate governance and finance in East Asia, $1^{\text {st }}$ Vol. Asian Development Bank, Manilla.

Audra, B., \& White, J., (2015). The effect of institutional ownership on firm transparency and information production. Journal of Financial Economics, 117(3), 508-533.

Azzam, I., (2010). The impact of institutional ownership and dividend policy on stock returns and volatility: evidence from Egypt. International Journal of Business, 15(4), 443-458.

Beattie, V., \& Thomson, S. J. (2007). Lifting the lid on the use of content analysis to investigate intellectual capital disclosure. Accounting Forum, 31, 129-163.

Bedard, J., \& Gendron, Y. (2010). Strengthening the financial reporting system: can audit committees deliver? International Journal of Auditing, 14(2), 174-210.

Belkaoui, A. R. (2004). Accounting Theory. $5^{\text {th }}$ edition. Thomson Learning.

Bhasin, M. L., Makarov, R. R., \& Orazalin, N. S. (2012). Determinants of voluntary disclosure in the banking sector: An empirical study. International Journal of Contemporary Business Studies, 3(3), 245-259.

Botosan, C. A. (1997). Disclosure level and the cost of equity capital. The Accounting Review, 72(3), 323-349.

Braiotta, L., Gazzaway, R. T., Colson, R., \& Ramamoorti, S. (2010). The Audit Committee Handbook. Canada: John Wiley \& Sons, Inc.

Chakroun, R. (2013). Family control, the board of directors' independence and extent of voluntary disclosure in the annual reports: the case of Tunisian companies. Journal of Business Studies Quarterly, 5(1), 22-42.

Chakroun, R. \& Matoussi, H., (2012). Determinants of the extent of voluntary disclosure in the annual reports of the Tunisian firms. Accounting and Management Information Systems, 11(3), 335-370.

Cornett, M. M., Marcus, A. J., Saunders, A. S., \& Tehranian, H. T. (2006). Earning management, corporate governance, and true financial performance. Available at SSRN: https://ssrn.com/abstract=886142., [9 March 2018].

Crane, A. D., Michenaud, S., \& Weston, J. P. (2016). The effect of institutional ownership on payout policy: evidence from index thresholds. The Review of Financial Studies, 29(6), 1377-1408.

Darmadi, S. (2013). Corporate Governance Disclosure in The Annual Report: An Exploratory Study on Indonesian Islamic banks. Humanomics, 29(1), 4-23.

Dulacha, G. B. (2007). Determinants of voluntary disclosure in Kenyan Companies annual reports. African Journal of Business Management, 1(5), 113-128.

Fama, E. F., \& Jensen, M. C. (1983). Separation of ownership and control. Journal of Law and Economics, 26(2), 301-325.

Forum for Corporate Governance in Indonesia (2000). The Corporate Governance Series.

Gantyowati, E. \& Nugraheni, R. L. (2014). The impact of financial distress status and corporate governance structures on the level of voluntary disclosure within annual reports of firms. (Case study non-financial firms in Indonesia over the period 2009-2011). Journal of Modern Accounting and Auditing, 10(4), 389-403.

Gregory, M.F., Bosch, F.A.J.V., \& Henk, V. (2004). The importance of disclosure in corporate governance self-regulation across Europe: a review of the winter report and the EU action plan. International Journal of Disclosure and Governance, 1(2), 146-159.

Habbash, M., Hussainey, K., \& Awad, A. E. (2016). The determinants of voluntary disclosure in Saudi Arabia: an empirical study. International Journal of Auditing and Performance Evaluation, 12(3), 13-236. 
Hendriksen, E. S. \& Breda, M. F. V. (2001). Accounting Theory, $5^{\text {th }}$ Ed. Boston: Southern Methodist University.

Hossain, M., \& Reaz, M. (2007). The determinants and characteristics of voluntary disclosure by Indian banking companies. Corporate Social Responsibility and Environmental Management, 14(5), 274-288.

Huang, C. J. (2010). Board, ownership and performance of banks with a dual board system: evidence from Taiwan. Journal of Management and Organization, 16(2), 219-234

IFCASI (2014). International Financial Corporation Advisory Service in Indonesia. The Indonesia corporate governance manual. Jakarta: OJK dan IFC.

Indonesia Financial Services Authority. (2014). Financial Services Authority Regulation No. 33/POJK.04/2014. Concerning Directors and Commissioners of Public Companies. Jakarta: Financial Services Authority.

Indonesia Financial Services Authority. (2015). Financial Services Authority Regulation. No. 55/POJK.04/2015. Concernings establishment and guidelines for audit committee work. jakarta: financial services authority.

Jensen, M. C., \& Meckling, W. H. (1976). Theory of the firm: managerial behaviour, agency costs and ownership structure. Journal of Financial Economics, 3(4), 305-360.

Jiang, H., Habib, A., \& Hu, B. (2011). Ownership concentration, voluntary disclosures and information asymmetry in New Zealand. The British Accounting Review, 43(1), 39-53.

Kangarlouei, S. J., Birjandi, H. A., \& Motavassel, M. (2013). The effect of ownership structure on voluntary disclosure in Tehran Stock Exchange. International Journal of Business Analytics and Intelligence, 1(1), 22-31.

Karim, K. E., Pinsker, R., \& Robin, A. (2013). Firm size and the voluntary disclosure of nonfinancial information by private versus public firm managers. Managerial Auditing Journal, 28(9), 866892.

Kaya, D. (2014). The influence of firm-specific characteristics on the extent of voluntary disclosure in XBRL: Empirical analysis of SEC filings. International Journal of Accounting and Information Management, 22(1), 2-17.

Li, J., Mangena, M., \& Pike, R. (2012). The effect of audit committee characteristics on intellectual capital disclosure. The British Accounting Review, 44(2), 98-110.

Lundholm, R., \& Winkle, M. V. (2006). Motives for the disclosure and non-disclosure: A framework and review of the evidence. Accounting and Business Research, 36, 43-48.

Madi, H. K., Ishak, Z., \& Manaf, N. A. (2014). The impact of audit committee characteristics on corporate voluntary disclosure. International Conference on Accounting Studies. ICAS 2014.

Mokhtari, Z., \& Makerani, K. F. (2013). Relationship of institutional ownership with firm value and earning quality: Evidence from Tehran Stock Exchange. International Journal of Economy. 2(7), 495-502.

Monks, R. A. G., \& Minow, N. (2011) Corporate Governance 5th edition. United Kingdom: John Wiley \& Son Ltd.

Nandi, S., \& Ghosh, S. (2012). Corporate governance attributes, firm characteristics and the level of corporate disclosure: Evidence from the Indian listed firms. Decision Science Letters, 2(1), 45-58.

Rouf, A. (2011). Corporate characteristics, governance attributes and the extent of voluntary disclosure in Bangladesh. African Journal of Business Management, 5(19), 7836-7845.

Sanjaya, I.P.S., \& Young, L. (2012). Voluntary disclosure and earnings management at bank companies listed in Indonesia Stock Exchange. China-USA Business Review, 11(3), 368-374.

Scaltrito, D. (2016). Voluntary disclosure in Italy: firm-specific determinants an empirical analysis of Italian listed companies. EuroMed Journal of Business, 11(2), 272-303.

Sihombing, J., \& Pangaribuan, H. (2017). A study of corporate governance structure, disclosure and information asymmetry in indonesia banking industry. Jurnal Akuntansi, 21(2), 156-169.

Solomon, J. (2010). Corporate governance and accountability. $3^{\text {rd }}$ edition. United Kingdom: John Wiley \& Son Ltd.

Utama, A. A. (2012). Company disclosure in Indonesia: Corporate governance practice, ownership structure, competition and total assets. Asian Journal of Business and Accounting, 5(1), 75108. 
Uyar, A., Kilic, M., \& Bayyurt, N. (2013). Association between firm characteristics and corporate voluntary disclosure: Evidence from Turkish listed companies. Intangible Capital, 9(4), 10801112.

Watson, A., Shrives, P., \& Marston, C. (2002). Voluntary disclosure of accounting ratios in the UK. British Accounting Review, 34, 289-313.

Wijantini. (2006). Voluntary disclosure in the annual reports of financially distressed companies in Indonesia. Gadjah Mada International Journal of Business, 8(3), 343-365. 